Jurnal Akuntansi dan Bisnis

Available online http://ojs.uma.ac.id/index.php/jurnalakunbisnis

Analisis Faktor-Faktor Yang Mempengaruhi Kebijakan Dividen

\title{
Analysis of Factors Affecting Dividend Policy
}

\author{
Wenny Anggeresia Ginting \\ Munawarah \\ Universitas Prima Indonesia, Indonesia \\ E-mail: gintinganggresiawenny@gmail.com
}

\begin{abstract}
Abstrak
Kebijakan dividen adalah keputusan perusahaan untuk membayarkan sebagian atau seluruh laba yang diperoleh kepada pemegang saham yang ditetapkan dalam RUPS (Rapat Umum Pemegang Saham). Variabel independen dalam penelitian ini adalah laba bersih (profitabilitas) yang diukur melalui ROE, arus kas dan utang (leverage) yang diukur melalui DER. Sedangkan variabel dependen dalam penelitian ini adalah kebijakan dividen yang diukur dengan DPR. Tujuan dari penelitian ini adalah untuk menguji dan menganalisis apakah ROE, arus kas dan DER memiliki pengaruh signifikan terhadap DPR pada Perusahaan Jasa dan Investasi yang terdaftar di Bursa Efek Indonesia periode 2012-2014. Penelitian ini menggunakan data sekunder dengan metode studi dokumentasi berupa laporan keuangan tahunan perusahaan dari tahun 2012-2014. Pendekatan yang digunakan dalam penelitian adalah kuantitatif dengan metode pengambilan sampel purposive sampling. Dari total 60 perusahaan, hanya diambil 17 perusahaan yang memenuhi kriteria untuk dijadikan sampel. Teknik analisis data yang digunakan adalah regresi linear berganda. Nilai R Square $\left(\mathrm{R}^{2}\right)$ adalah 0,328 yang mengindikasikan bahwa variasi variabel kebijakan dividen dapat dijelaskan oleh variasi variabel laba bersih, arus kas, dan utang sebesar 32,8 \%. Hasil penelitian menunjukkan bahwa secara simultan laba bersih, arus kas dan utang berpengaruh positif dan signifikan terhadap kebijakan dividen. Secara parsial laba bersih (profitabilitas) tidak berpengaruh signifikan terhadap kebijakan dividen, arus kas berpengaruh positif dan signifikan terhadap kebijakan dividen, dan utang(leverage) berpengaruh signifikan terhadap kebijakan dividen.

Kata Kunci : Profitabilitas; Arus Kas; Leverage; Kebijakan Dividen
\end{abstract}

\begin{abstract}
Dividend policy is the company's decision to pay part or all of the profits earned to shareholders specified in the GMS (General Meeting of Shareholders). The independent variables in this study are net profit (profitability) measured through ROE, cash flow and debt (leverage) as measured through DER. While the dependent variable in this research is dividend policy measured by DPR. The purpose of this research is to test and analyze whether ROE, cash flow and DER have significant influence to DPR on Service and Investment Company listed in Indonesia Stock Exchange period 2012-2014. This study uses secondary data with documentation study method in the form of annual financial statements of the company from 2012-2014. The approach used in this research is quantitative with purposive sampling sampling method. Of the 60 companies, only 17 companies were selected to meet the criteria for sampling. Data analysis technique used is multiple linear regression. The value of $R$ Square $\left(R^{2}\right)$ is 0.328 which indicates that the variation of dividend policy variables can be explained by variation of net income, cash flow, and debt variable by $32.8 \%$. The results showed that simultaneously net income, cash flow and debt have a positive and significant impact on dividend policy. Partially net profit (profitability) has no significant effect on dividend policy, cash flow has positive and significant influence to dividend policy, and debt (leverage) have a significant effect on dividend policy.
\end{abstract}

Keywords : Profitability; Cash flow; Leverage; Dividend Policy 
Abstrak ditulis dalam Bahasa Inggris sebanyak 150 - 200 kata [Font: Cambria, size: 9, Italic] Keywords: terdiri dari 3 sampai 5 kata dan/atau kelompok kata, sesuai urutan abjad, dan antara kata kunci dipisahkan oleh titik koma (;) [Font: Cambria, size: 10, Italic]

How to Cite: Nama belakang, Nama depan singkat. Tahun, Judul artikel huruf besar setiap awal kata, kecuali kata sambung [Font: Cambria, size: 9, normal], Jurnal Ilmu Pemerintahan dan Sosial Politik UMA, Vol (No): Halaman. 


\section{PENDAHULUAN}

Untuk mencapai tujuan laba, manajer keuangan perusahaan harus memaksimalkan nilai perusahaan dengan mempertimbangkan keputusan keuangan mengenai penggunaan dana, memperoleh dana, dan pembagian laba. Keputusan investasi sangat berpengaruh pada awal berdirinya perusahaan, sedangkan keputusan pendanaan merupakan keputusan yang mendukung bagaimana membiayai investasi tersebut. Pembagian laba akan menjadi sangat penting mengingat sumber dana yang diperoleh tidak semata-mata berasal dari dana sendiri, namun dana dari pihak lain yang menyertakan modalnya pada perusahaan. Keputusan pembagian laba dikenal dengan istilah kebijakan dividen. Perusahaan yang ingin bertumbuh berarti harus menahan sebagian keuntungannya, namun di lain pihak perusahaan juga ingin memakmurkan para pemegang saham dengan mem-bagikan sebagian keuntungannya, sebagai sinyal positif dari perusahaan kepada pihak luar. Manajer harus memperhatikan kas yang tersedia di perusahaan karena kas sangat diperlukan dalam membeli aktiva untuk melanjutkan aktivitas di perusahaan. Posisi arus kas merupakan hasil rasio kas akhir tahun dengan laba setelah pajak.

Semakin kuat posisi arus kas, maka semakin besar kemungkinan perusahaan membayar dividen. Adanya perbedaan asumsi yang mendasari permintaan atau kebutuhan terhadap pembayaran dividen menyebabkan perlu kebijakan tegas dari manajer. Jika tujuan dividen dapat memberikan sinyal positif perusahaan kepada investor, maka sudah seharusnya dividen wajib dibayarkan. Sebaliknya Adanya perbedaan preferensi pemegang saham dalam melihat kebijakan dividen perusahaan membuat perbedaan dalam pemberian dividen.

Bagi yang membutuhkan penghasilan saat ini tentu akan menyukai pembayaran dividen melalui dividen payout ratio yang tinggi, sedangkan pihak yang tidak begitu membutuhkan penghasilan dalam waktu dekat, lebih senang jika perusahaan menahan sebagian laba bersih perusahaan dengan mengharapkan prinsip opportunity cost melalui dana yang mereka tanamkan.

Tujuan penelitian ini adalah untuk menguji dan menganalisis pengaruh laba, arus kas, dan utang, terhadap kebijakan dividen pada Perusahaan Jasa dan Investasi yang terdaftar di BEI periode 2012 - 2014.

Berdasarkan pada uraian latar belakang di atas, maka rumusan masalah yang peneliti rancang antara lain :

Apakah laba, arus kas, dan utang berpengaruh secara simultan dan parsial terhadap kebijakan dividen pada Perusahaan Jasa dan Investasi yang terdaftar di BEI periode 2012 - 2014.

\section{Tinjauan Pustaka}

Laba bersih perusahaan (net income after tax) merupakan laba bersih setelah dikurangi dengan beban pajak, merupakan salah satu elemen yang dipertimbangkan perusahaan untuk membagi dividen atau tidak. Namun demikian, jika perusahaan rugi bukan berarti tidak membagi dividen. Jika perusahaan rugi dan membagi dividen berarti laba ditahan perusahaan bersaldo negatif. Jika profitabilitas perusahaan meningkat, maka pembayaran dividen dalam jumlah besar. Dan sebaliknya jika profitabilitas perusahaan rendah, maka pembagian laba juga akan sejalan. 
Kestabilan laba juga menunjukkan kemampuan menjaga laba pada level yang telah ditetapkan sesuai dengan keinginan dan hanya dapat dicapai jika hal-hal lain dianggap konstan, kestabilan penjualan dan unsur-unsur biaya produksi dan biaya operasional juga mampu dijaga. Oleh sebab itu sangat penting bagi perusahaan untuk meningkatkan laba bersih demi kelangsungan operasional perusahaan dan juga harga saham karena besarnya laba sangat berpengaruh terhadap tinggi dan rendahnya pembayaran dividen kepada pemegang saham. Laba bersih juga merupakan faktor yang menaikkan harga saham perusahaan sehingga menjadi daya tarik kepada para investor baru yang akan menanamkan modal kedalamnya.

$\mathbf{H}_{1}$ : Profitabilitas berpengaruh secara positif dan signifikan terhadap Kebijakan Dividen pada Perusahaan Jasa dan Investasi yang terdaftar di BEI periode 2012 - 2014.

Dividen dapat dijadikan sebagai suatu sinyal positif yang menunjukkan kemampuan manajer dalam mengelola keuangan perusahaan, khususnya mengenai aliran kas, karena dalam membayarkan dividen pada pemegang saham tentunya membutuhkan arus kas yang banyak. Menurut Hery (2013:194) arus kas memberikan informasi yang berguna mengenai kemampuan perusahaan dalam menghasilkan kas dari kegiatan operasi, melakukan investasi, melunasi kewajiban, dan membayar dividen. Nilai arus kas mencerminkan jumlah kas yang dihasilkan oleh perusahaan untuk para pemegang sahamnya dalam kurun waktu satu tahun. Namun faktanya sebuah perusahaan menghasilkan arus kas yang tinggi tidak selalu berarti bahwa kas yang dilaporkan pada neracanya juga akan tinggi, arus kas tersebut mungkin digunakan dalam berbagai hal. Dapat disimpulkan bahwa arus kas merupakan faktor penting dalam menentukan pembagian dividen kepada para investor karena diperlukan adanya ketersediaan kas yang kuat sehingga kemampuan pembayaran dividen tinggi.

$\mathbf{H}_{2}$ : Arus Kas berpengaruh positif dan signifikan terhadap Kebijakan Dividen pada Perusahaan Jasa dan Investasi yang terdaftar di BEI periode 2012 - 2014.

Utang merupakan kewajiban badan usaha atau perusahaan kepada pihak ketiga yang dibayarkan melalui cara menyerahkan asset atau jasa perusahaan dalam jangka waktu tertentu sesuai dengan kesepakatan dimana kewajiban ini terjadi sebagai akibat dari transaksi di masa lalu. Pembiayaan dengan utang merupakan salah satu alternatif dalam mendukung kebutuhan dana untuk menjamin keberhasilan keputusan investasi perusahaan. Utang juga dapat meningkatkan atau mengurangi tingkat pengembalian bagi pemegang ekuitas. Dalam masa sulit tingkat pengembalian pemegang ekuitas berkurang melalui penggunaan hutang, tetapi jika terjadi sebaliknya, tingkat pengembalian meningkat. Jika perusahaan memiliki kewajiban yang besar dan harus segera dibayar, pemegang saham harus dikorbankan, yaitu menunda atau mengurangi pembayaran dividen. Jika perusahaan dalam kondisi solvabilitas yang kurang menguntungkan biasanya perusahaan akan menahan untuk membagikan laba. Hal ini dapat disebabkan karena laba yang diperoleh lebih diutamakan untuk memperbaiki struktur modal perusahaan. Otomatis 
porsi pembagian dividen kepada pemegang saham akan mengalami pengurangan. Semakin besar utang yang harus dibayar maka semakin besar dana yang harus disediakan sehingga akan mengurangi jumlah dividen yang akan dibayar kepada para investor.

$\mathbf{H}_{3}$ : Leverage berpengaruh secara negatif dan signifikan terhadap Kebijakan Dividen pada Perusahaan Jasa dan Investasi yang terdaftar di BEI periode 2012 - 2014.

\section{METODE PENELITIAN}

Metode pengumpulan data yang diguna-kan oleh peneliti adalah metode dokumentasi, yaitu dengan mengumpulkan data sekunder (laporan tahunan perusahaan yang menjadi sampel penelitian). Dalam penelitian ini, yang menjadi subjek pengumpulan data yaitu perusahaan jasa dan investasi yang terdaftar di Bursa Efek Indonesia periode 2012-2014.

Populasi dalam penelitian ini adalah perusahaan-perusahaan jasa dan investasi yang terdaftar di Bursa Efek Indonesia (BEI) sebanyak 6o perusahaan.

Sampel penelitian menggunakan teknik purposive sampling dimana terdapat kriteria-kriteria tertentu. Kriteria yang digunakan dalam penentuan sampel penelitian ini antara lain :

- Perusahaan Jasa dan Investasi yang terdaftar di Bursa Efek Indonesia periode 2012-2014.

- Perusahaan Jasa dan Investasi yang menghasilkan laba di Bursa Efek Indonesia periode 2012-2014.

- Perusahaan Jasa dan Investasi yang membagikan dividen di Bursa Efek Indonesia periode 2012-2014.
- Berdasarkan kriteria pemilihan sampel, maka sampel penelitian menjadi 17 perusahaan, sehingga observasi pengamatan menjadi $17 \times 3$ $=51$ sampel.

Dalam penelitian ini model analisis data yang dipakai adalah regresi liner berganda (multiple linier regression) dengan menggunakan rumus seperti berikut:

$$
Y=\alpha+\beta_{1} X_{1}+\beta_{2} X_{2}-\beta_{3} X_{3}+e
$$

Dimana :

$\mathrm{Y}=$ Variabel Y (Kebijakan Dividen)

$\mathrm{X}_{\mathbf{1}}=$ Variabel $\mathrm{X}_{\mathbf{1}}$ (Laba Bersih)

$\mathrm{X}_{2}=$ Variabel X2 (Arus Kas)

$\mathrm{X}_{3}=$ Variabel $\mathrm{X}_{3}$ (Utang)

$\beta_{1}, \beta_{2}, \beta_{3}=$ Koefisien regresi variabel

$\alpha=$ Konstanta

$\mathrm{e}=$ Term of error (tingkat kesalahan)

Descriptive Statistics

\begin{tabular}{|l||l|l|l|l|}
\hline & Minimum & Maximum & Mean & Std. Deviation \\
\hline ROE & .000 & .461 & .1532 & .098359 \\
& & & 2 & \\
ARUS KAS & 2695.000 & 10636445 & 1038 & 1824552.526 \\
& & 000 & 261.6 & 204 \\
& & & 0784 & \\
DER & .000 & 2.019 & .7275 & .483799 \\
& & & 7 & .3901 \\
DPR & .001 & 1.949 & .384813 \\
Valid N & & & 6 & \\
(listwise) & & & & \\
\hline
\end{tabular}

\section{HASIL DAN PEMBAHASAN}

\section{Statistik Deskriptif}

Berdasarkan tabel diatas diperoleh bahwa laba pada perusahaan Jasa dan Investasi yang terdaftar di BEI tahun 20122014 memiliki nilai terendah $0,000(0 \%)$, dan nilai tertinggi sebesar $0,461(46,1 \%)$. Rata-rata laba sebesar 0,15322 (15,32\%). Emiten yang memiliki nilai minimum adalah PT. MNC Investama, Tbk (BHIT) 
tahun 2013, dan maksimum adalah PT. Surya Citra Media, Tbk (SCMA) tahun 2013.

Arus kas memiliki nilai terendah 2.695, dan nilai tertinggi 10.636 .445 , dan rata-rata sebesar 1.038.261.61. Emiten yang memiliki nilai minimum adalah PT. Pool Advista Indonesia, Tbk (POOL) tahun 2012, dan maksimum adalah PT. Elang Mahkota Teknologi, Tbk (EMTK) tahun 2014.

Utang memiliki nilai terendah 0,000 (0\%) dan nilai tertinggi sebesar 2,019 (201,9\%), dan rata-rata 0,72757 (72,75\%). Emiten yang memiliki nilai minimum adalah PT. Pudjiadi and Sons, Tbk (PNSE) tahun 2012, dan maksimum adalah PT. PT. Gema Grahasarana , Tbk (GEMA) tahun 2012.

Kebijakan dividen memiliki nilai terendah $0,001(0,1 \%)$ dan nilai tertinggi sebesar 1,949 (19,49\%). Rata-rata sebesar 0,39016 (39,02\%). Emiten yang memiliki nilai minimum adalah PT. Surya Citra Media , Tbk (SCMA) tahun 2013, dan nilai maksimum adalah PT. Elang Mahkota Teknologi, Tbk EMTK tahun 2014.

\section{Hasil Uji Asumsi Klasik}

\section{Uji Normalitas}

Berdasarkan uji normalitas dapat diperoleh hasil sebagai berikut :

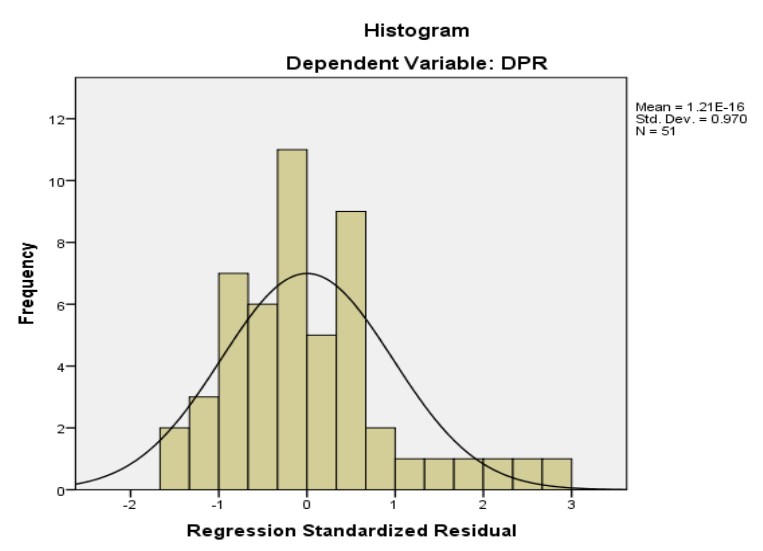

Gambar 4.2.1 Grafik Histogram

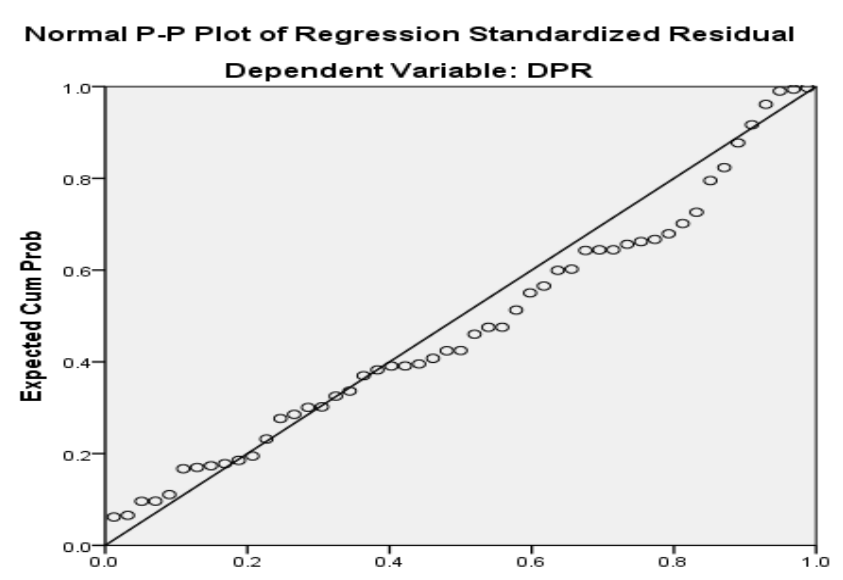

Gambar Normal P-PFóted Cum Prob

Hasil pengujian secara grafik baik melalui P-Plot dan Histogram menunjukkan bahwa data terdistribusi normal. Pada Normal P-Plot menunjukkan bahwa titiktitik menyebar disekitar garis diagonal, dan pada Histogram menunjukkan kurva berbentuk lonceng yang tidak menceng ke kiri atau kanan. Hal ini juga dapat didukung melalui uji statistik melalui Uji NonParametrik dengan Kolmogorov Smirnov.

\section{Tabel Kolmogorov Smirnov Test}

One-Sample Kolmogorov-Smirnov Test

\begin{tabular}{|ll|l|}
\hline & & $\begin{array}{l}\text { Unstandardize } \\
\text { d Residual }\end{array}$ \\
\hline $\mathrm{N}$ & & 51 \\
Normal Parameters ${ }^{\mathrm{a}, \mathrm{b}}$ & Mean & .0000000 \\
& Std. Deviation & .31544407 \\
Most Extreme Differences & Absolute & .119 \\
& Positive & .119 \\
& Negative & -.061 \\
Test Statistic & & .119 \\
Asymp. Sig. (2-tailed) & & $.067 \mathrm{c}$ \\
\hline
\end{tabular}

a. Test distribution is Normal.

b. Calculated from data.

c. Lilliefors Significance Correction.

Sumber : Hasil Pengolahan SPSS, 2017 
Nilai Kolmogorov Smirnov sebesar 0,119 dengan nilai signifikansi sebesar $0,067>0,05$. Dapat disimpulkan bahwa residual terdistribusi normal.

\section{Uji Multikolinearitas}

Uji multikolinearitas adalah sebuah situasi yang menunjukkan adanya korelasi atau hubungan kuat antara dua variable bebas atau lebih dalam sebuah model regresi berganda.

\section{Tabel Hasil Uji Multikolonieritas}

\begin{tabular}{|c|c|c|c|}
\hline \multicolumn{4}{|c|}{ Coefficients $^{a}$} \\
\hline \multirow{2}{*}{\multicolumn{2}{|c|}{ Model }} & \multicolumn{2}{|c|}{ Collinearity Statistics } \\
\hline & & $\begin{array}{l}\text { Toleranc } \\
\text { e }\end{array}$ & VIF \\
\hline & (Constant) & & \\
\hline & ROE & .987 & 1.013 \\
\hline & ARUS KAS & .975 & 1.026 \\
\hline & DER & .987 & 1.013 \\
\hline
\end{tabular}

a. Dependent Variable: DPR

Sumber : Hasil Pengolahan SPSS, 2017

Berdasarkan pada tabel diatas, nilai tolerance dari ROE sebesar 0,987>0,10, dan VIF 1,013<10, arus kas sebesar $0,975>0,10$ dan VIF sebesar $1,026<10$ dan DER sebesar 0,987>0,10 dan VIF sebesar $1,013<10$, maka dapat disimpulkan bahwa variabel tersebut tidak saling berkorelasi atau dinyatakan terbebas dari multikolinearitas.

\section{Uji Autokorelasi}

Pada penelitian ini, digunakan uji Durbin-Watson (DW test) untuk mendeteksi ada atau tidaknya korelasi pada model regresi yang diuji.

\section{Tabel Hasil Uji Autokorelasi}

Model Summaryb

\begin{tabular}{|l|l|l|l|l|l|}
\hline Model & $R$ & $\begin{array}{l}\text { R } \\
\text { Square }\end{array}$ & $\begin{array}{l}\text { Adjusted } \\
\text { R Square }\end{array}$ & $\begin{array}{l}\text { Std. Error of } \\
\text { the Estimate }\end{array}$ & $\begin{array}{l}\text { Durbin- } \\
\text { Watson }\end{array}$ \\
\hline 1 & $.573^{\mathrm{a}}$ & .328 & .285 & .325356 & 2.014 \\
\hline
\end{tabular}

a. Predictors: (Constant), DER, ROE, ARUS KAS

b. Dependent Variable: DPR

Sumber : Hasil Pengolahan SPSS, 2017

Berdasarkan pada tabel diatas, nilai Durbin-Watson (d) sebesar 2,014 akan dibandingkan dengan nilai tabel yang mempunyai nilai signifikan 5\%, jumlah sampel (n) $=51$ dan jumlah variabel independen $(\mathrm{k})=3$. Berdasarkan tabel Durbin-Watson (d) pada signifikasi 0,05, maka diperoleh nilai batas atas $\left(\mathrm{d}_{\mathrm{u}}\right)=$ 1,6754 dan nilai batas bawah $\left(\mathrm{d}_{1}\right)=1,4273$ serta nilai $4-d_{u}=4-1,6754=2,3246$. Dengan demikian, maka dapat disimpulkan bahwa tidak terjadi autokorelasi, sebab nilai d terletak antara batas atas $\left(\mathrm{d}_{\mathrm{u}}\right)$ dan 4 - $d_{u}$ yaitu $1,6754<2,014<2,3246\left(d_{u}<d<\right.$ $4-d u)$.

\section{Uji Heteroskedastisitas}

Pengujian heteroskedastisitas dapat dilakukan dengan dua cara yaitu melalui analisis grafik dan uji Glejser. Analisis grafik dapat dilihat melalui grafik scatterplot berikut :

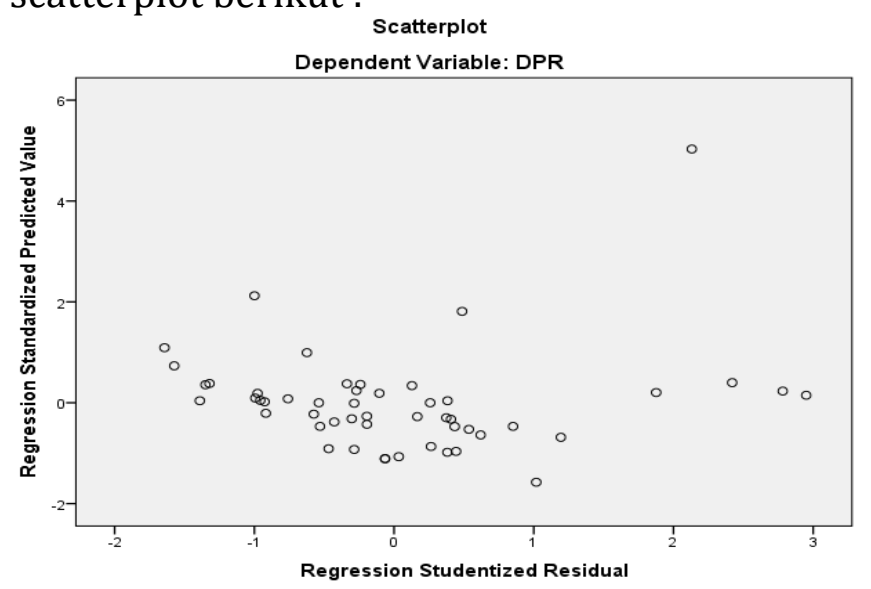

Gambar Grafik Scatterplot 
Sumber : Hasil Pengolahan SPSS, 2017

Sedangkan uji statistik melalui uji glejser dapat dilihat sebagai berikut:

\begin{tabular}{|c|c|c|c|c|c|}
\hline \multicolumn{6}{|c|}{ Coefficients $^{\mathrm{a}}$} \\
\hline \multirow[t]{2}{*}{ Model } & \multicolumn{2}{|c|}{$\begin{array}{l}\text { Unstandardiz } \\
\text { ed } \\
\text { Coefficients }\end{array}$} & \multirow{2}{*}{\begin{tabular}{|l} 
Stand \\
ardize \\
d \\
Coeffi \\
cients \\
Beta \\
\end{tabular}} & \multirow[t]{2}{*}{$t$} & \multirow[t]{2}{*}{ Sig. } \\
\hline & B & \begin{tabular}{|l} 
Std. \\
Error \\
\end{tabular} & & & \\
\hline $\begin{array}{ll}1 & \text { (Const } \\
\text { ant) }\end{array}$ & .197 & .071 & & 2.781 & .008 \\
\hline ROE & .330 & .285 & .157 & 1.159 & .252 \\
\hline $\begin{array}{l}\text { ARUS } \\
\text { KAS }\end{array}$ & $\begin{array}{l}3.528 \\
\text { E-8 }\end{array}$ & .000 & .312 & 2.284 & .067 \\
\hline DER & -.065 & .058 & -.153 & -1.128 & .265 \\
\hline
\end{tabular}

a. Dependent Variable: ABS_UT

\section{Tabel Hasil Uji Heteroskedastisitas}

Sumber : Hasil Pengolahan SPSS, 2017

Berdasarkan pada pengujian heteroskedastisitas melalui grafik scatterplot terlihat titik-titik menyebar secara acak di atas dan di bawah angka 0 pada sumbu $Y$, serta tidak membentuk pola tertentu. Dan uji grafik melalui uji Glejser pada tabel diatas, menunjukkan bahwa nilai signifikasi pada ROE (X1) sebesar $0,252>0,05$, nilai arus kas (X2) sebesar 0,067>0,05, dan nilai DER (X3) sebesar 0,265>0,05 maka dapat disimpulkan bahwa data dinyatakan terbebas dari heteroskedastisitas.

\section{Hasil Analisis Data Penelitian}

Model analisis data yang digunakan dalam penelitian ini adalah model analisis data regresi linear berganda. Model ini digunakan bertujuan untuk mengetahui pengaruh variabel bebas dan variabel terikat.

\begin{tabular}{|c|c|c|c|}
\hline \multirow[t]{2}{*}{ Model } & \multicolumn{2}{|c|}{$\begin{array}{l}\text { Unstandardized } \\
\text { Coefficients }\end{array}$} & \multirow{2}{*}{\begin{tabular}{|l}
$\begin{array}{l}\text { Standardized } \\
\text { Coefficients }\end{array}$ \\
Beta
\end{tabular}} \\
\hline & B & $\begin{array}{l}\text { Std. } \\
\text { Error }\end{array}$ & \\
\hline 1 (Constant) & .436 & .117 & \\
\hline ROE & -.143 & .471 & -.037 \\
\hline ARUS KAS & $1.044 \mathrm{E}-7$ & .000 & .495 \\
\hline DER & -.181 & .096 & -.228 \\
\hline
\end{tabular}

a. Dependent Variable: DPR

Tabel Hasil Analisis Regresi

Sumber : Hasil Pengolahan SPSS, 2017

Dari tabel diatas, maka dapat disimpulkan suatu model persamaan regresi linear berganda sebagai berikut:

$$
\begin{aligned}
\mathrm{DPR}= & 0,436-0,143 \mathrm{ROE}+0,0000001044 \\
& \text { ArusKas }-0,181 \mathrm{DER}
\end{aligned}
$$

\section{Koefisien Determinasi Hipotesis}

Hasil pengujian nilai koefisien determinasi $\left(\mathrm{R}^{2}\right)$ dapat dilihat pada tabel sebagai berikut:

\section{Tabel Koefisien Determinasi}

Model Summary
\begin{tabular}{|l|l|l|l|l|l|}
\hline Model & $\mathrm{R}$ & $\begin{array}{l}\mathrm{R} \\
\text { Square }\end{array}$ & $\begin{array}{l}\text { Adjusted R } \\
\text { Square }\end{array}$ & $\begin{array}{l}\text { Std. Error } \\
\text { of the } \\
\text { Estimate }\end{array}$ & $\begin{array}{l}\text { Durbin } \\
\text { Watson }\end{array}$ \\
\hline 1 & $.573^{\mathrm{a}}$ & .328 & .285 & .325356 & 2.014 \\
\hline
\end{tabular}

a. Predictors: (Constant), DER, ROE, ARUS KAS

b. Dependent Variable: DPR

Sumber : Hasil Pengolahan SPSS, 2017

Berdasarkan hasil uji koefisien determinasi diperolah nilai $R$ Square $\left(\mathrm{R}^{2}\right)$ sebesar 0,328 yang berarti ROE, ArusKas, dan DER dapat menjelaskan variabel kebijakan dividen sebesar 32,8\%, sedangkan sisanya 67,2\% 
dijelaskan oleh faktor lain yang tidak dijelaskan dalam penelitian ini.

\section{ANOVA}

\begin{tabular}{|l|l|l|l|l|l|}
\hline Model & $\begin{array}{l}\text { Sum of } \\
\text { Squares }\end{array}$ & df & $\begin{array}{l}\text { Mean } \\
\text { Square }\end{array}$ & F & Sig. \\
\hline 1 Regression & 2.429 & 3 & .810 & 7.648 & $.000^{\mathrm{b}}$ \\
$\quad$ Residual & 4.975 & 47 & .106 & & \\
$\quad$ Total & 7.404 & 50 & & & \\
\hline
\end{tabular}

a. Dependent Variable: DPR

b. Predictors: (Constant), DER, ROE, ARUS KAS

Sumber :Hasil Pengolahan SPSS, 2017

\section{Pengujian Hipotesis Secara Simultan Tabel Uji Statistik F}

Berdasarkan hasil uji simultan atau uji F diperoleh nilai Fhitung sebesar 7,648 dengan tingkat sig 0,000. Sementara nilai Ftable adalah 2,80. Maka F hitung $>F_{\text {tabel }}(7,648$ $>2,80)$ dan tingkat sig $<0,05(0,000<$ 0,05). Dengan demikian dapat disimpulkan bahwa variable laba (ROE), Arus Kas dan Hutang (DER) secara simultan berpengaruh signifikan terhadap kebijakan deviden (DPR).

\section{Pengujian Hipotesis Secara Parsial Tabel Uji Statistik t Coefficients $^{\mathrm{a}}$}

\begin{tabular}{|ll|l|l|}
\hline \multicolumn{2}{|l|}{ Model } & \multicolumn{1}{l|}{} \\
\hline $1 \quad$ (Constant) & 3.726 & Sig. \\
\hline & ROE & -.304 & .001 \\
& ARUS KAS & 4.086 & .000 \\
& DER & -1.893 & .045 \\
\hline
\end{tabular}

a. Dependent Variable: DPR

Sumber : Hasil Pengolahan SPSS, 2017

Berdasarkan hasil uji parsial (uji t) pada tabel IV.10 maka dapat dijelaskan sebagai berikut :
1. Variabel laba (ROE) memiliki nilai thitung $<$ tabel $(0,304<1,67528)$ dengan tingkat signifikasi 0,762 > 0,05 maka dapat disimpulkan bahwa laba (ROE) secara parsial tidak berpengaruh signifikan terhadap kebijakan dividen (DPR).

2. Variabel arus kas memiliki nilai thitung $>$ tabel $(4,086>1,67528)$ dengan tingkat signifikasi $0,000<0,05$ maka dapat disimpulkan bahwa arus kas secara parsial berpengaruh signifikan terhadap kebijakan dividen (DPR).

3. Variabel utang (DER) memiliki nilai $t_{\text {hitung }}>t_{\text {tabel }}(1,893>1,67528)$ dengan tingkat signifikasi 0,045 $<0,05$ maka dapat disimpulkan bahwa utang secara parsial berpengaruh signifikan terhadap kebijakan dividen.

\section{Pembahasan Hasil Penelitian}

\section{Pengaruh Laba Terhadap Kebijakan Dividen}

Laba yang diukur melalui ROE dengan nilai thitung $<t_{\text {tabel }}(0,304<1,67528)$ dengan tingkat signifikasi 0,762 >0,05 maka dapat disimpulkan bahwa laba (ROE) secara parsial tidak berpengaruh signifikan terhadap kebijakan dividen (DPR) pada Perusahaan Jasa dan Investasi yang terdaftar di Bursa Efek Indonesia periode 2012-2014.

Laba bersih bukan merupakan faktor utama yang harus diperhatikan oleh pihak manajemen untuk membuat keputusan dalam menentukan besar dividen yang akan dibagikan, karena meskipun laba bersih yang dihasilkan sangat rendah, perusahaan tetap membayar dividen kepada pemegang saham. Hal ini dapat dilihat dari data perusahaan yang diteliti dimana ada beberapa perusahaan jasa dan investasi yang tetap membagikan dividen 
meskipun laba bersih yang dihasilkan jauh lebih rendah pada tahun tersebut. Hasil ini juga bertolak belakang dengan Teori "dividen tidak relevan" dari Modigliani dan Miller Secara teori yang menyatakan bahwa besar kecilnya Dividend Payout ratio ditentukan oleh laba bersih sebelum pajak (EBIT). Menurut beliau tidak ada pajak yang dibebankan atas pendapatan perusahaan. Sementara pada praktiknya pajak pasti ada sehingga dalam penelitian ini digunakan laba bersih setelah dikurangi beban-beban termasuk diantaranya pajak. Laba bersih yang dihasilkan perusahaan dianggap sebagai penentu utama dalam membagi dividen, namun kenyataannya dividen lebih bergantung pada arus kas yang tersedia.

\section{Pengaruh Arus Kas Terhadap Kebijakan Dividen}

Arus kas dengan nilai thitung $>t_{\text {tabel }}$ $(4,086>1,67528)$ dan nilai signifikan $0,000<0,05$ menunjukkan bahwa arus kas secara parsial berpengaruh positif dan signifikan terhadap kebijakan dividen pada Perusahaan Jasa dan Investasi yang terdaftar di Bursa Efek Indonesia periode 2012-2014.

Arus kas dapat membantu memberikan informasi yang berguna mengenai kemampuan perusahaan dalam menghasilkan kas dari kegiatan operasi, melakukan investasi, melunasi kewajiban, dan membayar dividen. Hasil penelitian ini mendukung hipotesis peneliti bahwa arus kas adalah sumber informasi bagi investor untuk menilai kemampuan perusahaan dalam memenuhi kewajibannya membayar dividen dan pendanaan eksternal. Hasil penelitian mendukung teori "Signaling Hypotesis" yang menyatakan bahwa kenaikan pembayaran dividen merupakan suatu sinyal pada para investor bahwa manajemen perusahaan meramalkan penghasilan yang baik di masa mendatang. Ini menunjukkan bahwa manajemen mampu mengelola posisi arus kas dengan baik sehingga semakin kuat posisi kas, maka semakin besar juga kemampuan dalam membayarkan dividen.

\section{Pengaruh Utang Terhadap Kebijakan Dividen}

Utang yang diukur melalui DER dengan nilai $t_{\text {hitung }}>t_{\text {tabel }}(1,893>1,67528)$ dengan tingkat signifikasi 0,045 $<0,05$ dan nilai signifikan 0,286 $>0,05$ menunjukkan bahwa utang secara parsial berpengaruh negatif dan signifikan terhadap kebijakan dividen pada Perusahaan Jasa dan Investasi yang terdaftar di Bursa Efek Indonesia periode 2012-2014.

Perusahaan dengan jumlah utang yang tinggi cenderung meminimumkan pembayaran dividen kepada investor karena sebagian besar pendapatan akan digunakan untuk melunasi pinjaman. Hasil ini sejalan dengan teori dari Gumanti (2013:84), bahwa semakin tinggi beban utang yang harus ditanggung perusahaan, semakin besar pula porsi laba yang harus dialihkan kepada pelunasan utang sekaligus berarti mengurangi porsi dividen termasuk juga sisa dana yang masuk kembali ke perusahaan. Hal ini mendukung teori "signaling hypotesis" dimana besar kecilnya pembayaran dividen menunjukan sinyal tertentu bagi pemegang saham. Tingginya utang menyebabkan menurunnya pembayaran dividen sehingga penurunan ini diyakini investor sebagai suatu sinyal bahwa perusahaan sedang menghadapi kesulitan karena sebagian 
dana nya digunakan untuk menyelesaikan kewajibannya. Bagi pihak yang merasa utang perusahaan yang semakin bertambah dapat menyebabkan penurunan nilai perusahaan, maka itu harus diseimbangkan pertumbuhan perusahaan dengan kesejahteraan pemegang saham sehingga dapat meningkatkan kembali nilai perusahaan.

\section{SIMPULAN, IMPLIKASI DAN KETERBATASAN \\ Kesimpulan}

Berdasarkan hasil analisis data dan pembahasan sebelumnya, maka dapat ditarik beberapa kesimpulan bahwa secara simultan variabel laba bersih yang diukur melalui ROE, Arus Kas, dan Utang yang diukur melalui DER berpengaruh signifikan terhadap Kebijakan Dividen (DPR) pada Perusahaan Jasa dan Investasi yang Terdaftar di Bursa Efek Indonesia periode 2012-2014. Dan untuk pengujian secara parsial diperoleh bahwa laba bersih yang diukur melalui ROE tidak berpengaruh signifikan terhadap kebijakan dividen yang diukur melalui DPR. Arus Kas secara parsial berpengaruh positif dan signifikan terhadap kebijakan dividen (DPR), sedangkan Variabel Utang yang diukur melalui DER secara parsial berpengaruh negatif dan signifikan terhadap Kebijakan Dividen pada Perusahaan Jasa dan Investasi yang Terdaftar di Bursa Efek Indonesia periode 2012-2014.

\section{Implikasi}

Berdasarkan hasil penelitian maka dapat dilihat bahwasanya dalam menilai kebijakan pemberian dividen, manajer keuangan perusahaan harus tahu betul kemana aliran kas perusahaan. Sekalipun tinggi permintaan pasar yakni pemegang saham akan naiknya pembayaran dividen melalui ukuran Dividen Payout Ratio (DPR), manajer tidak perlu meresponnya dengan pemberian yang setimpal. Manajer juga harus mempertimbangkn alternative sumber pendanaan agar tidak lebih banyak menggunaka sumber dana melalui utang baik jangka pendek maupun jangka panjang, yang akan berdampak pada besar kecilnya pembayaran dividen. Utang yang begitu tinggi akan berdampak pada kemungkinan kebangkrutan karena biaya yang terlalu tinggi. Terlihat pada hasil penelitian dengan banyaknya sumber penggunaan dana melalui utang dibandingkan dengan ekuitas, menunjukkan bahwa perusahaan Jasa dan Investasi ini tidak banyak menggunakan sumber dana melalui modal sendiri atau modal yang disetor pemegang saham. Sehingga mereka akan lebih fokus pada bagaimana pengembalian kewajiban tersebut sesegera mungkin. Hal ini juga sejalan dengan laba bersih yang mampu diperoleh dari sumber pendanaan ekuitas, tidak mampu pengaruhi tingginya pembayaran dividen.

\section{Keterbatasan}

Penelitian ini memiliki beberapa keterbatasan, yaitu :

1. Penelitian hanya menggunakan rentang periode 3 tahun pengamatan yaitu tahun 2012-2014. 
2. Variabel independen yang digunakan yaitu ROE, Arus Kas, dan DER hanya mampu menjelaskan $32,8 \quad \%$ pengaruh-nya terhadap kebijakan dividen (DPR), sedangkan sisanya $67,2 \%$ harusnya dapat dijelaskan oleh faktor-faktor lain seperti posisi likuiditas, rencana ekspansi, kesempatan investasi, stabilitas pendapatan dan lain-lain yang dapat mempengaruhi kebijakan dividen.

3. Objek pengamatan yang diteliti hanya terbatas pada Perusahaan Sektor Jasa dan Investasi, sehingga hasil penelitian ini tidak dapat digeneralisir pada perusahaan lainnya. Perbedaan aktivitas, ruang lingkup, produk yang diperjual belikan tentu akan membuat hasil penelitian ini akan berbeda.

\section{DAFTAR PUSTAKA}

Anil, K. dan Kapoor, S. 2008. Determinant of Dividend Payout Ratio - A Study of Indian Information Technology Sector. International Research Journal of Finance and Economics. (15): $63-71$.

Andriyanti, Lina. Wirakusuma, Made Gede. 2014. Pengaruh Profitabilitas, Leverage, Dan Arus Kas Bebas Terhadap Kebijakan Deviden Dengan Good Corporate Governance Sebagai Variabel Pemoderasian. E-Jurnal Akuntansi. (l) : 245-262.

Aqel,Saher. 2016. An Empirical Investigation of Corporate Dividend Payout Policy in an Emerging Market: Evidence from Palestine Securities Exchange. Research Journal of Finance and Accounting. $7(6)$.
Brealey, et.al. 2008. Dasar-Dasar Manajemen Keuangan Perusahaan. Penerbit Erlangga.

Brigham, Eugene F. dan Houston,Joel F. 2010. Dasar-dasar Manajemen Keuangan (Essentials of Financial Management). Buku Satu, Edisi Kesebelas. Salemba Empat. Jakarta.

Dhira, Wulandari, dan Wahyuni. 2010. Pengaruh Laba Bersih, Arus Kas Operasi, dan Ukuran Perusahaan Terhadap Kebijakan Dividen Pada Perusahaan Manufaktur Yang Terdaftar di BEI. Jurnal Ekonomi Akuntansi dan Manajemen (JEAM). 13 (2) : 72-86.

Ghozali, Imam. 2013. Aplikasi Analisis Multivariate dengan Program IBM SPSS 21. Cetakan Ketujuh. Semarang: Badan Penerbit Universitas Diponegoro.

Gumanti., Tatang Ary. 2013. Kebijakan Dividen: Teori, Empiris, dan Implikasi. Cetakan Pertama. Yogyakarta: UPP STIM YKPN.

Hadi, Nor. 2013. Pasar Modal (Acuan Teoritis dan Praktis Investasi di Instrumen Keuangan Pasar Modal). Ed. 1, Yogyakarta: Graha Ilmu.

Jayati dan Cahyonowati. 2014. Analisis Pengaruh Cash Flow Terhadap Kebijakan Dividen Perusahaan Dengan Size Perusahaan dan Life Cycle Perusahaan Sebagai Moderating Variable. Diponegoro Journal of Accounting. 3(2): 1-9.

Kapoor, S., K. Anil dan A. Misra. 2010. Dividend Policy Determinants of Indian FMCG Sector: A Factorial Analysis. Journal of Modern Accounting and Auditing. 6(9):50-64.

Kasmir. Analisis Laporan Keuangan. Cetakan Kelima. Jakarta: PT. Raja Grafindo Persada, 2012. 
Prihadi, Toto. 2010. Analisis Laporan Keuangan (Teori dan Aplikasi). Jakarta: PPM.

www.idx.go.id 